\title{
Mitogen-Activated Protein Kinase Regulates Dopamine Transporter Surface Expression and Dopamine Transport Capacity
}

\author{
José A. Morón, ${ }^{1 *}$ Irina Zakharova, ${ }^{1 *}$ Jasmine V. Ferrer, ${ }^{3}$ Gerald A. Merrill, ${ }^{4}$ Bruce Hope, ${ }^{1}$ Eileen M. Lafer, ${ }^{5}$ \\ Zhi Cheng Lin, ${ }^{2}$ Jia Bei Wang, ${ }^{7}$ Jonathan A. Javitch, ${ }^{3}$ Aurelio Galli, ${ }^{6 *}$ and Toni S. Shippenberg ${ }^{1 \star}$ \\ ${ }^{1}$ Behavioral Neuroscience Branch and ${ }^{2}$ Molecular Neurobiology Branch, National Institute on Drug Abuse, Intramural Research Program, Baltimore, \\ Maryland 21224, ${ }^{3}$ Center for Molecular Recognition, College of Physicians and Surgeons, Columbia University, New York, New York 10032, ${ }^{4}$ Department of \\ Clinical Investigation, Brooke Army Medical Center, Houston, Texas 78234, Departments of ${ }^{5}$ Biochemistry and ${ }^{6}$ Pharmacology, University of Texas Health \\ Science Center, San Antonio, Texas 78229, and 7Department of Pharmaceutical Sciences, University of Maryland School of Pharmacy, Baltimore, Maryland 21201
}

The dopamine transporter (DAT) regulates the clearance of dopamine (DA) released into the extracellular space and is an important site on which psychostimulants act to produce their effects. Here, we show that mitogen-activated protein kinase (MAPK) regulates the transport capacity and intracellular trafficking of DAT. Incubation of striatal synaptosomes or epitope-tagged human DAT (hDAT) human embryonic kidney (HEK) 293 cells with the MAPK kinase (MEK) inhibitors 1,4-diamino-2,3-dicyano-1,4-bis(oaminophenylmercapto) butadiene and 2-(2-amino-3-methoxyphenyl)-4H-1-benzopyran-4-one decreased DA uptake in a concentrationand time-dependent manner. Kinetic studies revealed a decrease in the capacity of transport $\left(V_{\max }\right)$ but no change in $K_{\mathrm{m}}$. Immunoblotting confirmed labeling of $\mathrm{p} 42$ and 44 MAPK in untreated striatal synaptosomes and HEK 293 cells, consistent with constitutive MAPK activation, and the inhibitors used decreased MAPK phosphorylation. Biotinylation and confocal imaging studies showed that MAPK inhibition promoted the clathrin-associated redistribution of hDAT from the plasma membrane to the cytosol. In contrast, transient transfection of hDAT-expressing cells with constitutively active MEK increased the $V_{\max }$ of DA transport without altering $K_{\mathrm{m}}$. However, only a small increase in hDAT cell surface expression was seen. These data demonstrate an involvement of the MAPK cascade in regulating DAT transport capacity in striatum and that inhibition of this cascade decreases DAT cell surface expression in HEK 293 cells. Furthermore, they highlight the potential role of MAPK as a presynaptic mechanism that regulates DA signaling.

Key words: dopamine transporter; trafficking; epitope-tagged-hDAT; HEK 293 cells; MAPK; biotinylation

\section{Introduction}

Dopamine (DA) neurotransmission in the CNS is implicated in the regulation of motor activity, stress responsiveness, and motivational state (Giros and Caron, 1993; Hyman, 1996). Dysfunction of DA signaling contributes to various psychiatric and neurological disorders, including Parkinson's disease, schizophrenia, and drug addiction (Self and Nestler, 1995; Hyman, 1996). DA signaling is terminated by the DA transporter (DAT), an integral membrane protein that is a member of the $\mathrm{Na}^{+}$- and $\mathrm{Cl}^{-}$dependent cotransporter gene family (Cass et al., 1991; Amara and Kuhar, 1993). Pharmacological blockade of DAT by psychostimulants inhibits the reuptake of DA from the extracellular

\footnotetext{
Received Jan. 17, 2003; revised June 23, 2003; accepted June 30, 2003.

This work was partially supported by National Institutes of Health Grants DA14684 (A.G.), DA11495, and MH57324 (J.A.J.). We thank Dr. Tom Blanpeid and Dr. Mike Ehlers for construct preparation and Kris Kahilg and Dr. Lucia Carvelli for technical assistance. We also acknowledge Dr. George Uhl for assistance in methodological development.

*J.A.M., I.Z., A.G., and T.S.S. contributed equally to this work.

Correspondence should be addressed to Toni S. Shippenberg, Integrative Neuroscience Section, National Institute on Drug Abuse, Intramural Research Program, 5500 Nathan Shock Drive, Baltimore, MD 21224. E-mail: tshippen@intra.nida.nih.gov.

Copyright $\odot 2003$ Society for Neuroscience $\quad$ 0270-6474/03/238480-09\$15.00/0
}

space, resulting in increased extracellular DA levels and augmented receptor stimulation (Horn, 1990). Although pharmacological and genetic ablation (Grace, 1995; Jones et al., 1998) studies indicate a critical role of DAT in the maintenance of DA neuronal homeostasis, the endogenous mechanisms regulating DAT expression and activity are poorly understood.

DAT is synthesized in the cell soma and transported to the plasma membrane for use. The biosynthetic recovery of DAT in vivo requires up to 2 weeks, suggesting the existence of posttranslational mechanisms that respond more rapidly to an increased demand for DA clearance (Fleckenstein et al., 1996). Indeed, DA receptor stimulation and changes in second messenger production modulate DA uptake in vitro and in vivo (Meiergerd et al., 1993; Ortiz et al., 1995; Mayfield and Zahniser, 2001). Kinase-mediated changes in the activity of DAT and other biogenic amine transporters have been reported (Melikian et al., 1994; Vaughan et al., 1997; Zhang et al., 1997; Apparsundaram et al., 1998; Ramamoorthy and Blakely, 1999). PKC activation decreases DA transport capacity $\left(V_{\max }\right)$ with little change in substrate affinity (Copeland et al., 1996; Huff et al., 1997; Vaughan et al., 1997). PKC activation also induces transporter phosphorylation and decreased DAT cell surface expression (Melikian et al., 
1994; Pristupa et al., 1998; Daniels and Amara, 1999). Inhibition of PKA or calmodulin protein kinase also alters DAT transport capacity (Uchikawa et al., 1995; Batchelor and Schenk, 1998), suggesting a more global role of protein kinases in regulating DAT activity. Whether the effects of these kinases result from alterations in transporter phosphorylation or activation of other kinase cascades is unclear. $\mathrm{N}$-terminal truncation of DAT has recently been shown to abolish phorbol ester- and substance $\mathrm{P}$ receptor-stimulated phosphorylation without impairing transporter internalization (Granas et al., 2003).

Mitogen-activated protein kinases (MAPKs) are serinethreonine kinases that regulate gene transcription, cell growth, and differentiation (Schlessinger and Ullrich, 1992; Treisman, 1996). Their involvement in the regulation of cytoskeleton dynamics and G-protein-coupled receptor (GPCR) signaling has been demonstrated (Drewes et al., 1992; Blenis, 1993).

MAPKs are highly expressed in the CNS and are activated by various stimuli, including calcium, growth factors, and various GPCRs (Rosen et al., 1994; Vanhoutte et al., 1999). Activation of MAPK may occur by both PKC-dependent and -independent mechanisms. $\mathrm{D}_{2}$ DA receptor stimulation increases DA transport capacity and activates the MAPK cascade by increasing intracellular calcium and activating PKC (Yan et al., 1999; Mayfield and Zahniser, 2001). In addition, other GPCRs and ionotropic neurotransmitter receptors (Welch and Justice, 1996; Thompson et al., 2000; Liu et al., 2001) that activate MAPK profoundly alter DAT activity. In view of these findings and those demonstrating MAPK-induced phosphorylation of cytosketal proteins implicated in protein trafficking, we examined the involvement of MAPKs in regulating DA uptake and DAT trafficking. We show that MAPK inhibition decreases DA transport capacity in rat striatal synaptosomes and EM4 cells (Robbins and Horlick, 1998) stably expressing FLAG-tagged human DAT (hDAT). Confocal microscopy and biotinylation studies show that this decrease is associated with the clathrin-dependent redistribution of DAT from the plasma membrane to the cytosol. Furthermore, in contrast to MAPK inhibition, transient transfection of hDATexpressing cells with constitutively active MAPK kinase (MEK) results in overexpression of phosphorylated MAPK and increased DA transport.

\section{Materials and Methods}

Synaptosome preparation. Male Sprague Dawley rats (250-300 gm; Charles River Laboratories, Wilmington, MA) were housed in a colony room maintained at constant temperature $\left(20^{\circ} \mathrm{C}\right)$ and humidity for a week before experiments. Rats had ad libitum access to food and water, and a $12 \mathrm{hr}$ light/dark cycle was used. Experiments were approved by the National Institute on Drug Abuse Animal Care and Use Committee. Rats were killed by decapitation, and their brains were removed to an icecooled dish. The striatum was dissected and placed in ice-cold Krebs'Ringer's buffer (in mm: $125 \mathrm{NaCl}, 1.2 \mathrm{KCl}, 1.2 \mathrm{MgSO}_{4}, 1.2 \mathrm{CaCl}_{2}, 22$ $\mathrm{NaHCO}_{3}, 1 \mathrm{NaH}_{2} \mathrm{PO}_{4}$, and 10 glucose, pH 7.4) containing $0.32 \mathrm{M}$ sucrose and homogenized using a glass homogenizing tube and a Teflon pestle. After centrifugation at $1000 \times g$ for $10 \mathrm{~min}$ at $4^{\circ} \mathrm{C}$, the pellet was discarded, and the supernatant was centrifuged at $16,000 \times g$ for $15 \mathrm{~min}$. The $\mathrm{P} 2$ pellet was placed on ice until resuspension.

Immunoblot analysis of extracellular signal-regulated kinase 1 and 2 activity. Synaptosomes were incubated with the selective MEK inhibitors (Tocris, Ballwin, MO) 1,4-diamino-2,3-dicyano-1,4-bis (o-aminophenylmercapto) butadiene (U0126) $(50 \mu \mathrm{M})$ and 2-(2-amino-3-methyoxyphenyl)-4H-1benzopyran-4-one (PD98059) (50 $\mu \mathrm{M})$ (Alessi et al., 1995; Duncia et al., $1998)$ at $37^{\circ} \mathrm{C}$ for $30 \mathrm{~min}$. The concentration used selectively inhibits phosphorylation of the p42 [extracellular signal-regulated kinase 2 (ERK2)] and p44 (ERK1) forms of MAPK (Cussac et al., 1999; Yan et al., 1999). Because phosphatidylinositol 3-kinase (PI 3-kinase) activates MAPK in several cell lines (Hawes et al., 1995; Igishi and Gutkind, 1998), the influence of the selective PI 3-kinase inhibitor 2-(4-morpholinyl)-8-phenyl-4H-1benzopyran-4-one (LY294002; Tocris) (Vlahos et al., 1994) on MAPK activity was also assessed. After incubation, synaptosomal fractions were solubilized, and the protein concentration for each sample was quantified. Equal amounts of protein from the fractions were separated on $10 \%$ acrylamide gels and transferred to polyvinylidene difluoride membranes (Millipore, San Jose, CA). Phosphorylated MAPK was determined with a monoclonal antibody raised against the p42 and p44 forms phosphorylated on both threonine and tyrosine residues (New England Biolabs, Beverly, MA). Detection was performed by enhanced chemiluminescence with a horseradish peroxidase-labeled secondary antibody (Amersham Biosciences, Piscataway NJ). Total MAPK was revealed with a polyclonal antibody against unphosphorylated and phosphorylated forms of p42 and p44 (New England Biolabs) followed by enhanced chemiluminescence detection. Membranes were placed in a Fluor-S multi-imager (Bio-Rad, Hercules, CA), and band densities were determined using Quantity One software (Bio-Rad).

$\left[{ }^{3} \mathrm{H}\right] \mathrm{DA}$ uptake in synaptosomes. Synaptosomes were preincubated with the indicated concentrations of MAPK inhibitors for $30 \mathrm{~min}$ at $37^{\circ} \mathrm{C}$ (unless otherwise noted) before performance of the uptake assay. After preincubation, samples were placed on ice, and $\left[{ }^{3} \mathrm{H}\right] \mathrm{DA}$ was added to initiate transport. The assay was performed in Krebs'-Ringer's buffer containing $0.64 \mathrm{~mm}$ ascorbic acid and $0.8 \mathrm{~mm}$ pargyline to inhibit ligand degradation. The final concentration of $\left[{ }^{3} \mathrm{H}\right] \mathrm{DA}(50 \mathrm{Ci} / \mathrm{mmol}$; Amersham Biosciences) was $0.1 \mu \mathrm{M}$, except for kinetic analyses, in which $\left[{ }^{3} \mathrm{H}\right] \mathrm{DA}$ concentrations were $0.025-1.5 \mu \mathrm{M}$. Tubes were incubated for 4 min at $37^{\circ} \mathrm{C}$. Nonspecific accumulation of $\left[{ }^{3} \mathrm{H}\right] \mathrm{DA}$ was determined in samples incubated at $4^{\circ} \mathrm{C}$. The assay was terminated by placing the tubes on ice and adding $5 \mathrm{ml}$ of ice-cold Krebs'-Ringer's buffer. The solutions were then filtered through Whatman (Clifton, NJ) GF/C glass microfiber filters presoaked in $0.1 \%$ polyethyleneimine to reduce nonspecific binding. After filtration, the filters were washed two times with $5 \mathrm{ml}$ of ice-cold Krebs'-Ringer's buffer. They were placed in scintillation vials, and $3 \mathrm{ml}$ of Bio-Safe II scintillation fluid (Research Biochemicals, Natick, MA) was added to each tube. Radioactivity was determined by liquid scintillation spectrometry. Kinetic parameters were determined by nonlinear regression fitting using Prism software (GraphPad; Microsoft, Redmond, WA).

Plasmid construction, transfection, and cell culture. The synthetic hDAT gene was tagged at the $\mathrm{N}$ terminus with a FLAG epitope and was subcloned into a bicistronic expression vector (Rees et al., 1996), creating a construct that expresses the synthetic hDAT from a cytomegalovirus promoter and the hygromycin resistance gene from an internal ribosomal entry site as described previously (Saunders et al., 2000). EM4 cells, human embryonic kidney (HEK) 293 cells stably transfected with a macrophage scavenger (R. Horlick, Pharmacopeia, Cranberry, NJ), were stably transfected with the FLAG-hDAT with LipofectAMINE (Invitrogen, San Diego, CA), and a stably transfected pool was selected in hygromycin $(250 \mu \mathrm{g} / \mathrm{ml})$ as described (Ferrer and Javitch, 1998). Cells were grown in DMEM supplemented with $10 \%$ fetal bovine serum (FBS) at $37^{\circ} \mathrm{C}$ and $5 \% \mathrm{CO}_{2}$. Previous studies have shown that addition of the $\mathrm{N}$-terminal FLAG tag does not alter $\left[{ }^{3} \mathrm{H}\right] \mathrm{DA}$ uptake by the transporter. Similarly, the ability of the transporter to produce substrate-induced currents is unaltered (Saunders et al., 2000).

An enhanced green fluorescent protein-C1-CLCA1 plasmid (pEGFPC1-CLCA1) was prepared by amplifying clathrin LCA1 from plasmid pPPal-2 with primers $5^{\prime}$-CATGCTCGAGTCATGGCTGAGTTGGATCC-3' and $5^{\prime}$-CATGGAATTGCTGGCTCTTCAATGCACC-3'. The resultant PCR product was cleaved with XhoI-EcoR1 and inserted into XhoIEcoR1-cleaved pEGFP-C1 (Clontech, Palo Alto, CA) to generate plasmid pEGFP-C1-CLCA1. The stable FLAG-hDAT-expressing EM4 cells were transiently transfected using the calcium phosphate transfection method with $1 \mu \mathrm{g}$ of pEGFP-C1-CLCA1 per $35 \mathrm{~mm}$ dish. The cells were treated with MAPK inhibitors 48 hours later as described above.

EM4 cells stably expressing FLAG-hDAT were transiently transfected with $3 \mu \mathrm{g}$ of wild-type MEK or the constitutively active MEK mutant S218ES222D (S. J. Mansour, University of Colorado, Boulder, CO) using $15 \mu \mathrm{l}$ of LipofectAMINE (Invitrogen) per T75 flask. Previous characterization of this mutant in HEK 293 cells revealed a significant elevation of phosphorylated ERK2 relative to that of cells transfected with wild-type MEK (Mansour et al., 
1994). Cells were incubated with lipid-cDNA complexes in Opti-MEM medium for $5 \mathrm{hr}$ at $37^{\circ} \mathrm{C}$ in a $\mathrm{CO}_{2}$ incubator, and then medium was replaced with DMEM and F-12 containing 10\% FBS. Forty-eight hours after transfection, cells were seeded into 24 -well plates for $\left[{ }^{3} \mathrm{H}\right] \mathrm{DA}$ uptake or into six-well plates for immunoblotting.

$\left[{ }^{3} H\right] D A$ uptake in FLAG-hDAT cells. EM4 cells stably transfected with FLAG-tagged DAT were seeded into 24-well plates $24 \mathrm{hr}$ before experiments and grown to confluence ( $\sim 250,000$ cells per well). After $1 \mathrm{hr}$ of serum starvation, cells were washed two times with Krebs' buffer (in mм: $120 \mathrm{NaCl}, 4.7 \mathrm{KCl}, 10 \mathrm{HEPES}, 5$ Tris, $2.2 \mathrm{CaCl}_{2}$, and 10 D-glucose, $\mathrm{pH} 7.4$ ) and then preincubated for 30 min with Krebs' buffer containing (in $\mu \mathrm{M}$ ): 50 ascorbic acid, 50 pargyline, and 12 '-fluoro-3,4-dihydroxy-5nitrobenzophenone at $37^{\circ} \mathrm{C}$ in the absence or presence of $50 \mu \mathrm{M}$ U0126 or PD98058. The cells were treated in quadruplicate wells with $\left[{ }^{3} \mathrm{H}\right] \mathrm{DA}(10$ $\mathrm{Ci} / \mathrm{mmol}$; Amersham Biosciences) in the continued presence or absence of inhibitor and various concentrations of unlabeled DA $(0.1-50 \mu \mathrm{M})$. The reaction mixture was incubated for $5 \mathrm{~min}$ at $25^{\circ} \mathrm{C}$ and then aspirated to terminate uptake. After three $1 \mathrm{ml}$ washes with ice-cold Krebs' buffer, cells were lysed with $300 \mu \mathrm{l}$ of $1 \%$ SDS. Radioactivity was measured in 4 $\mathrm{ml}$ of Bio-Safe II scintillation fluid (Research Biochemicals). Specific $\left[{ }^{3} \mathrm{H}\right] \mathrm{DA}$ uptake was defined as total uptake less nonspecific in the presence of $100 \mu \mathrm{M}$ cocaine.

$\left[{ }^{3} \mathrm{H}\right]$ Leucine uptake in FLAG-hDAT cells. $\left[{ }^{3} \mathrm{H}\right]$ Leucine uptake was examined using the conditions described above. Uptake was initiated by the addition of $15 \mathrm{~nm}\left[{ }^{3} \mathrm{H}\right]$ leucine (PerkinElmer Life Sciences, Boston, MA) together with $100 \mu \mathrm{M}$ unlabeled leucine and terminated by three rapid washes with ice-cold Krebs' buffer. Nonspecific uptake was defined with parallel assays on ice.

Immunofluorescence and confocal microscopy. Cells were incubated with $\mathrm{U} 0126$ or PD98059 $(50 \mu \mathrm{M})$ at $37^{\circ} \mathrm{C}$ for $30 \mathrm{~min}$. The steps for immunostaining were conducted at room temperature. The coverslips containing the cells (50-70\% confluent) were washed two times with PBS and fixed for 25 min with $4 \%$ paraformaldehyde. The cells were rinsed two times with PBS and blocked with 5\% normal goat serum diluted in $0.05 \%$ Triton X-100 and PBS (PBST) for $1 \mathrm{hr}$. The blocking solution was aspirated, and the cells were rinsed once with PBST. The coverslips were incubated with primary antibody (anti-FLAG M-2 monoclonal antibody; Sigma, St. Louis, MO) at a 1:3000 dilution in PBST for $1 \mathrm{hr}$. The primary antibody was aspirated, and the cells were washed three times with PBST. The cells were incubated with secondary antibody [goat anti-mouse IgG (heavy and light chain) tetramethylrhodamine isothiocyanate; Kirkegarrd \& Perry, Gaithersburg, MD] at a 1:200 dilution in PBST for $1 \mathrm{hr}$. The secondary antibody was removed, and cells were washed three times times with PBST and one time with PBS. Coverslips were then mounted onto slides with Crystal Mount (Biomedia, Foster City, CA) and allowed to dry. Confocal microscopy was performed on a Nikon (Melville, NY) Diaphot inverted microscope using a Bio-Rad MRC1024 confocal imaging system equipped with a kryptonargon laser and Lasersharp software (Bio-Rad). To minimize fluorescent bleed-through of the GFP emission into the red [tetramethylrhodamine (TMR)] image, images were obtained in a sequential manner. The GFP image was obtained using the $488 \mathrm{~nm}$ laser excitation line and a 522DF32 emission filter. The TMR image was obtained using only the $568 \mathrm{~nm}$ excitation wavelength with an HQ598DF40 emission filter. Images were obtained with a $100 \times$ oil immersion objective with a $z$-axis resolution of $1 \mu \mathrm{m}$ unless otherwise stated. Confocal images were quantified using the Image image analysis system, which determines the average fluorescent intensity (AFI) within a cursor-determined area. Two areas were identified and quantified for each cell: total cell and cytoplasm. Data were expressed as the ratio of cytoplasmic to total AFI. The AFI of DAT immunofluorescence was quantified by an experimenter blind to the treatment conditions.

Cell surface biotinylation and immunoblotting. EM4 cells stably transfected with FLAG-tagged DAT were seeded on six-well plates at a density of $1 \times 10^{6}$ cells per well $24 \mathrm{hr}$ before treatments. Cell surface biotinylation was performed as described by Apparsundaram et al. (1998) with some modifications. Cells were washed two times with Krebs' buffer (in mм: $120 \mathrm{NaCl}, 4.69 \mathrm{KCl}, 10 \mathrm{HEPES}, 5$ Tris, $2.19 \mathrm{CaCl}_{2}$, and $10 \mathrm{D}$-glucose, $\mathrm{pH} 7.4)$ at $37^{\circ} \mathrm{C}$ and then preincubated for $30 \mathrm{~min}$ with Krebs' buffer at $37^{\circ} \mathrm{C}$ in the absence or presence of $50 \mu \mathrm{M}$ PD98059. Cells were washed quickly with ice-cold PBS containing $0.1 \mathrm{~mm} \mathrm{CaCl}_{2}$ and $1 \mathrm{~mm} \mathrm{MgCl}$ (PBS/Ca-Mg) and treated with sulfo-NHS-sulfo-S-S-biotin (NHS-SS) $\left(1.5 \mathrm{mg} / \mathrm{ml}\right.$; Pierce, Rockford, IL) at $4^{\circ} \mathrm{C}$ for $1 \mathrm{hr}$ in PBS/Ca-Mg. Cells transiently transfected with wild-type or constitutively active MEK were treated with sulfo-NHS-SS-biotin $48 \mathrm{hr}$ after transfection. Biotinylating reagents were removed by washing at $4^{\circ} \mathrm{C}$ with $100 \mathrm{~mm}$ glycine in PBS/ $\mathrm{Ca}-\mathrm{Mg}$ twice; the reaction was further quenched by incubation with 100 $\mathrm{mm}$ glycine for $30 \mathrm{~min}$ at $4^{\circ} \mathrm{C}$. Cells were then quickly washed two times with ice-cold $\mathrm{PBS} / \mathrm{Ca}-\mathrm{Mg}$ before lysis with $1 \mathrm{ml}$ of radioimmunoprecipitation assay buffer (20 mm Tris, 20 mm EGTA, 1 mm DTT, 1 mm benzamidine, and $1 \%$ Triton X-100) supplemented with protease inhibitors (100 $\mu \mathrm{M}$ PMSF, $5 \mu \mathrm{g} / \mathrm{ml}$ leupeptin, and $5 \mu \mathrm{g} / \mathrm{ml}$ pepstatin) for $30 \mathrm{~min}$ at $4^{\circ} \mathrm{C}$ with constant shaking. Lysates were centrifuged at $14,000 \times g$ for 30 $\min$ at $4^{\circ} \mathrm{C}$. Biotinylated and nonbiotinylated proteins were separated by incubation with ImmunoPure immobilized streptavidin beads (Pierce) for $1 \mathrm{hr}$ at room temperature with constant mixing. Beads were washed three times with radioimmunoprecipitation assay buffer, and adsorbed proteins were eluted with Laemmli loading buffer containing 2-mercaptoethanol for $30 \mathrm{~min}$ at room temperature. Total cell lysates and biotinylated (cell surface) and nonbiotinylated proteins were separated by SDS-PAGE (7.5\%) and immunoblotted with a rat monoclonal antibody directed against the $\mathrm{N}$ terminus of the hDAT (1:2000; Chemicon, Temecula, CA) using an HRP-conjugated goat anti-rat antibody (1:5000; Santa Cruz Biotechnology, Santa Cruz, CA). Immunoreactive bands were visualized with ECL on Hypersensitive ECL film (Amersham Biosciences). Band densities were determined using Scion-Image software (Scion Corp., Frederick, MD).

\section{Results}

\section{Constitutive activation of MAPK in synaptosomes}

Analysis of immunoblots with antibodies directed against the phosphorylated forms of ERK1 and ERK2 (p44 and p42 isoforms of MAPK) revealed the presence of labeled bands in untreated striatal synaptosomes, consistent with previous reports of constitutive MAPK activation in this brain region (Flood et al., 1998; Gerfen et al., 2002). Figure 1 shows that incubation of synaptosomes with the MEK inhibitor U0126 significantly decreased phosphorylated ERK1 and ERK2 without affecting total MAPK levels (native and phosphorylated forms). A similar decrease was observed when striatal synaptosomes were incubated with PD98059. Incubation of synaptosomes with the PI 3-kinase inhibitor LY294002 did not alter the phosphorylation state of MAPK.

\section{MAPK inhibition downregulates DA uptake in synaptosomes} Incubation of striatal synaptosomes with U0126 (50 $\mu \mathrm{M})$ decreased DA uptake. A significant reduction of DA uptake was apparent after 5 min of preincubation, and a maximum decrease of $56 \pm 2 \%$ was observed after 30 min (Fig. 2A). PD98059 also significantly reduced DA uptake, but the magnitude of this effect was less than that produced by U0126 (Fig. 2A).

Incubation of synaptosomes with varying concentrations of the MEK inhibitors revealed that the decrease in DA uptake was concentration-dependent (Fig. 2 B). Concentrations as low as 0.1 $\mu \mathrm{M}$ significantly decreased DA uptake, and a maximum decrease was observed after addition of a $50 \mu \mathrm{M}$ concentration of either agent. Kinetic analysis showed that both inhibitors significantly decreased transport capacity $\left(V_{\max }\right)$ with no apparent change in DA affinity $\left(K_{\mathrm{m}}\right)$. The $V_{\max }$ values of DA uptake were reduced to $45 \pm 2$ and $80 \pm 5 \%$ of control values after incubation with U0126 and PD 98059, respectively (Table 1). The effect of U0126 on DA uptake and MAPK phosphorylation was greater than that produced by PD98059, consistent with the differing effects of these agents on MEK-1 and -2. U0126 inhibits MEK-1 and -2, whereas PD98059 only prevents the activation and phosphoryla- 

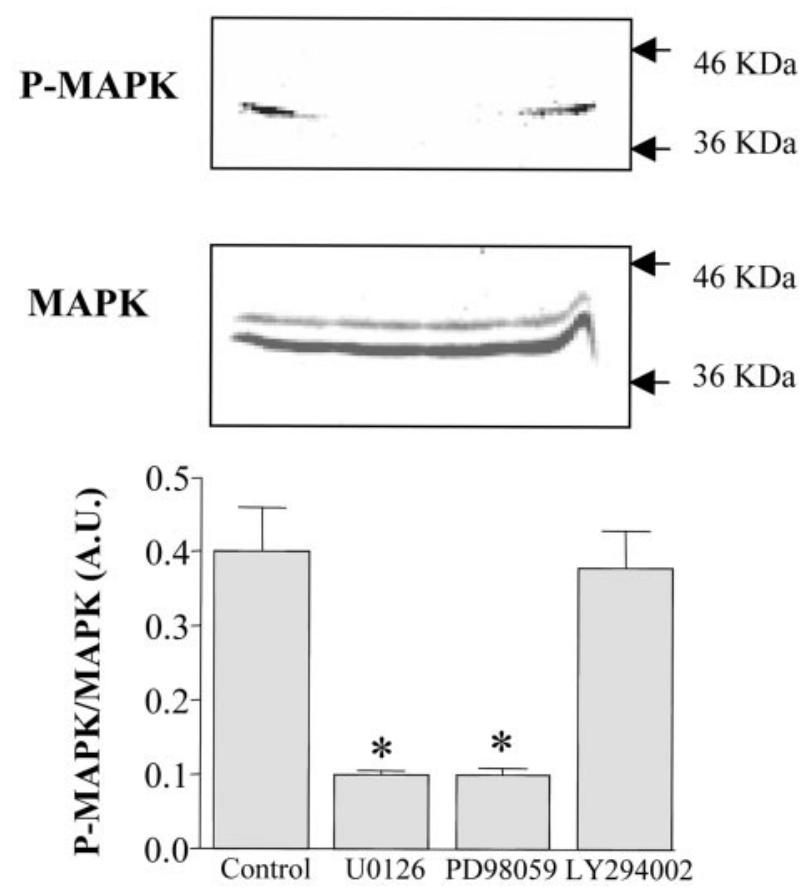

Figure 1. MAPK phosphorylation in striatal synaptosomes. Synaptosomes were incubated

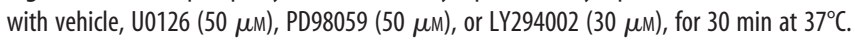
Solubilized synaptosomes were immunoblotted with anti-phospho-MAPK (ERK1 and ERK2) antibody. Total MAPK levels were detected with an antibody that recognized both native and phosphorylated forms of MAPK (a representative blot is shown). Quantification of MAPK phosphorylation was performed related to total MAPK as described in Materials and Methods. Data from three separate experiments were averaged, and mean values \pm SEM were plotted. * Significant difference compared with vehicle-treated controls ( $p<0.01$, Student's $t$ test).

tion of MEK-1 (Alessi et al., 1995). In contrast to the marked effects of the MEK inhibitors, incubation (5-30 min) of synaptosomes with the p38 MAPK inhibitor 4-(4-fluorophenyl)-2-(4methylsulfinylphenyl)-5-(4-pyridyl)-1H-imidazole $(1.0-50 \mu \mathrm{M}$; Lee et al., 1999) did not affect [ $\left.{ }^{3} \mathrm{H}\right] \mathrm{DA}$ uptake, suggesting the lack of a role for the p38 MAPK cascade in the regulation of basal DA uptake (data not shown).

\section{MAPK inhibition downregulates $\left[{ }^{3} \mathrm{H}\right] \mathrm{DA}$ uptake in FLAG-hDAT cells}

Cells stably transfected with FLAG-hDAT were used to examine the mechanisms mediating the inhibition of DA uptake produced by MAPK inhibition. Incubation of cells with PD98059 (50 $\mu \mathrm{M})$ markedly decreased levels of p44 and p42 forms of MAPK with no change in total MAPK levels (data not shown). As in synaptosomes, both MEK inhibitors decreased [ ${ }^{3} \mathrm{H}$ ]DA uptake in FLAGhDAT cells. PD98059 decreased the $V_{\max }$ to $\sim 76 \%$ of control values, and U0126 decreased the $V_{\max }$ of uptake to $\sim 32 \%$ of control values (Table 2). Thus, as in synaptosomes, the decrease in $V_{\max }$ for PD98059 was less than that produced by U0126. Moreover, as in synaptosomes, no significant change in $K_{\mathrm{m}}$ was observed in FLAG-hDAT cells. When PD98059 was only present during the uptake assay, $\left[{ }^{3} \mathrm{H}\right] \mathrm{DA}$ uptake was unaltered $(109.2 \pm$ $4.4 \%$ of control; $n=3$ ), demonstrating that the effects of the MEK inhibitors on DA uptake do not result from a direct interaction with DAT. Incubation of cells with either U0126 (50 $\mu \mathrm{M}$; $93.5 \pm 2.3 \%$ of control; $n=3$ ) or PD98059 (50 $\mu \mathrm{M} ; 98.7 \pm 0.4 \%$; $n=3$ ) for 30 min failed to alter $\left[{ }^{3} \mathrm{H}\right]$ leucine uptake in EM4 cells, demonstrating that the effect of MAPK inhibition on DAT is not
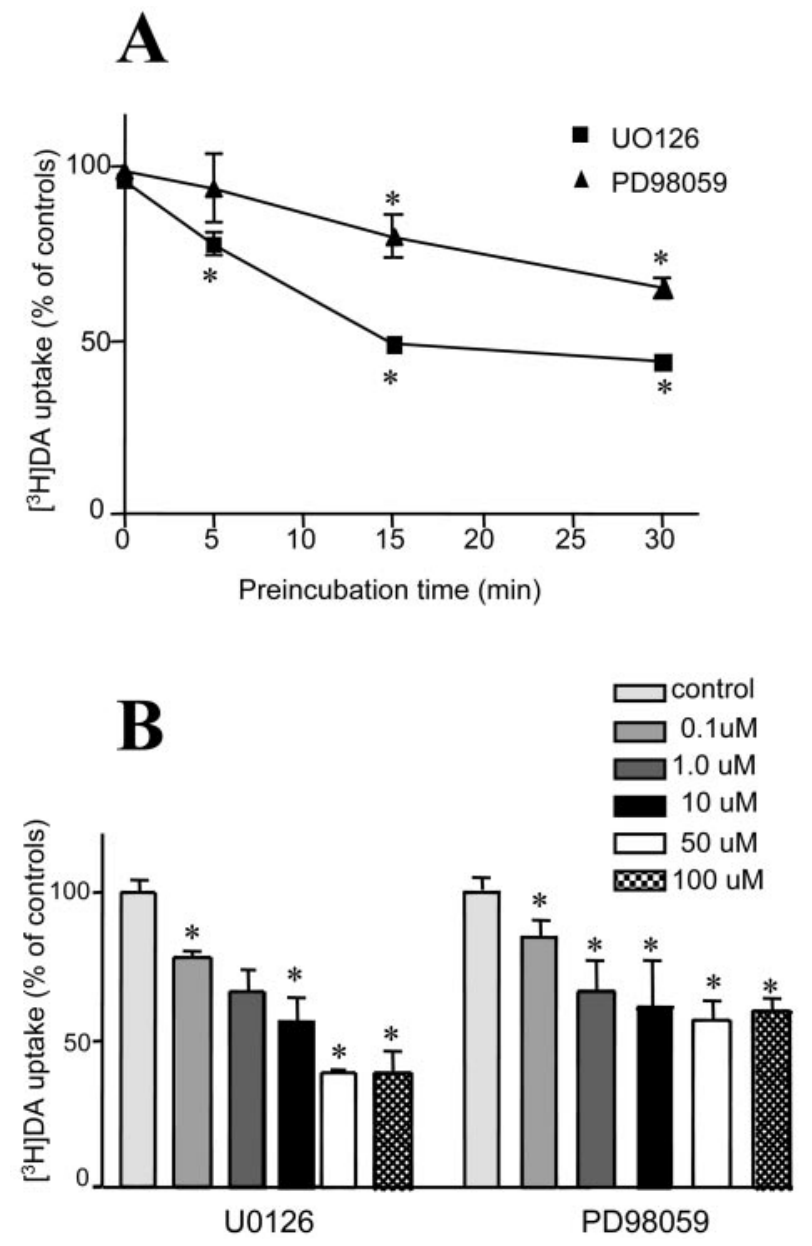

Figure 2. [ $\left.{ }^{3} \mathrm{H}\right] \mathrm{DA}$ uptake by U0126 or PD98059. A, Striatal synaptosomes were treated for the indicated times with U0126 (50 $\mu \mathrm{m})$ or PD98059 $(50 \mu \mathrm{m})$ before $\left[{ }^{3} \mathrm{H}\right] \mathrm{DA}$ uptake determination. $B$, Striatal synaptosomes were treated with the indicated concentrations of U0126 or PD98059 for 30 min before determination of uptake. Results are the mean \pm SEM of three experiments. ${ }^{*}$,* Significant difference compared with vehicle-treated controls $\left({ }^{*} p<0.05\right.$; Student's $t$ test).

Table 1. Effect of MAPK inhibitors on kinetic parameters of $\left[{ }^{3} \mathrm{H}\right] \mathrm{DA}$ uptake in striatal synaptosomes

\begin{tabular}{lll}
\hline Treatment & $K_{\mathrm{m}}(\mu \mathrm{m})$ & $V_{\max }\left(\mathrm{pmol} \cdot \mathrm{min}^{-1} \cdot \mathrm{mg} \mathrm{protein}^{-1}\right)$ \\
\hline Control & $0.50 \pm 0.06$ & $6.75 \pm 0.55$ \\
U0126 & $0.66 \pm 0.07$ & $3.02 \pm 0.19^{*}$ \\
PD98059 & $0.52 \pm 0.04$ & $5.41 \pm 0.35^{* *}$ \\
\hline
\end{tabular}

Synaptosomes were treated for $30 \mathrm{~min}$ with vehicle, $50 \mu \mathrm{M}$ U0126, or $50 \mu \mathrm{M}$ PD98059 before the determination of $\left[{ }^{3} \mathrm{H}\right] \mathrm{DA}$ uptake. $K_{\mathrm{m}}$ and $V_{\max }$ values are the mean \pm SEM from three separate experiments.

${ }^{*} p<0.01$, one-way ANOVA.

${ }^{* *} p<0.05$, one-way ANOVA.

a nonspecific effect that is observed with all plasma membrane transporters.

\section{MAPK inhibition decreases the cell surface distribution} of FLAG-hDAT

A decrease in $V_{\max }$ can arise from events that alter the turnover rate for DA transport or from a loss of transporter protein on the cell surface. To determine whether a reduction in the cell surface distribution of hDAT underlies the decrease in $V_{\max }$ produced by MAPK inhibition, immunofluorescence confocal microscopy was used. Incubation of cells with either PD98059 (50 $\mu \mathrm{M})$ or $\mathrm{U} 0126(50 \mu \mathrm{M})$ (data not shown) for $30 \mathrm{~min}$ resulted in a redis- 
Table 2. Effect of MAPK inhibitors on kinetic parameters of DAT activity in FLAGhDAT cells

\begin{tabular}{lll}
\hline Treatment & $K_{\mathrm{m}}(\mu \mathrm{m})$ & $V_{\max }\left(\mathrm{pmol} \cdot \mathrm{mg} \operatorname{protein}^{-1} \cdot \mathrm{min}^{-1}\right)$ \\
\hline Control & $3.46 \pm 0.57$ & $565.3 \pm 64.8$ \\
U0126 & $7.11 \pm 3.34$ & $184.6 \pm 54.4^{*}$ \\
Control & $2.75 \pm 0.16$ & $642.2 \pm 44.57$ \\
PD98059 & $3.00 \pm 0.26$ & $491.1 \pm 44.89^{* *}$ \\
\hline
\end{tabular}

Cells were treated for $30 \mathrm{~min}$ with vehicle, $50 \mu \mathrm{m}$ U0126, or $50 \mu \mathrm{m}$ PD98059. DAT activity was determined with $\left[{ }^{3} H\right] D A$ as described. $K_{\mathrm{m}}$ and $V_{\max }$ values are the mean $\pm S E M$ from three separate experiments.

${ }^{*} p<0.01$, paired $t$ test.

${ }^{* *} p<0.04$, paired $t$ test.

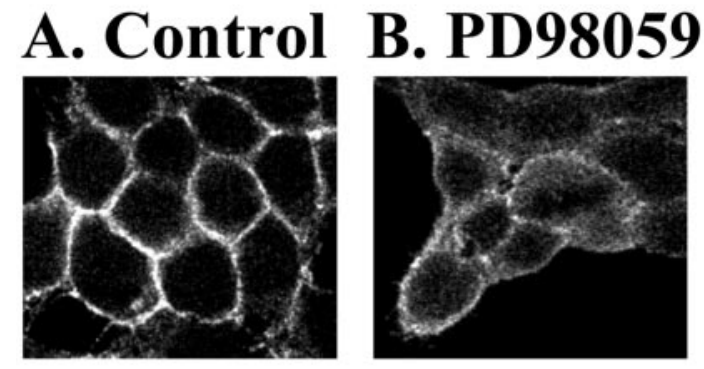

\section{Gallery}
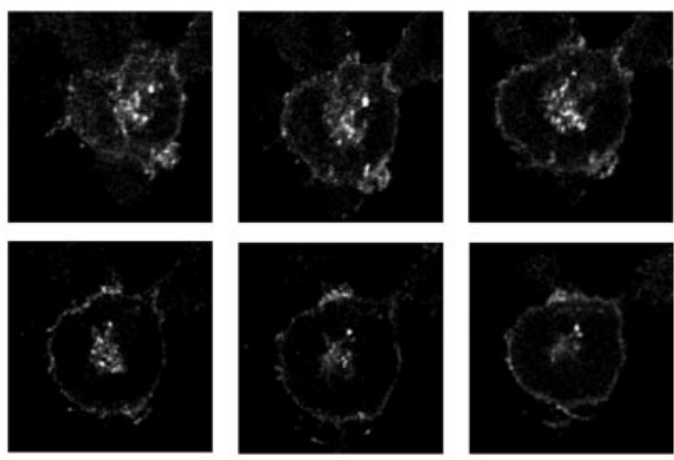

Figure 3. PD98059 induces a loss of hDAT cell surface expression. $A, B$, Confocal microscopic images of FLAG-hDAT cells in the absence $(A)$ or presence $(B)$ of $50 \mu \mathrm{m}$ PD98059 added to the bath solution for $30 \mathrm{~min}$. C, Z-sections of FLAG-hDAT cells treated with PD98059 go from the top to the bottom of the cells; the six confocal planes of $1 \mu \mathrm{m}$ in thickness show extensive intracellular immunofluorescence. The confocal microscopic images shown are representative of four different experiments.

tribution of the cellular expression pattern of hDAT. The immunofluorescence intensity of FLAG-hDAT on the cell surface was significantly reduced, and the cytosolic distribution of FLAGhDAT was increased (Fig. 3).

\section{MAPK inhibition promotes trafficking of FLAG-hDAT}

To determine whether hDAT intracellular accumulation may represent a trafficking event, the influence of concanavalin A (ConA), a plant lectin that prevents internalization by stabilizing cell surface integrity (Lis and Sharon, 1986), on PD98058- and U0126-induced redistribution of FLAG-hDAT (data not shown) was determined. Quantification of representative cells (Fig. 4) showed that the mean ratio of cytoplasmic to total AFI was $0.27 \pm$ $0.02(n=15)$ for control cells. Preincubation of cells with PD98059 significantly increased this value to $0.69 \pm 0.04(n=$ 22). In cells pretreated with ConA before incubation with PD98059 (Fig. 4C), the AFI ratio was $0.34 \pm 0.03(n=15)$. This value was significantly different (Tukey's test, $p \leq 0.01$ ) from that
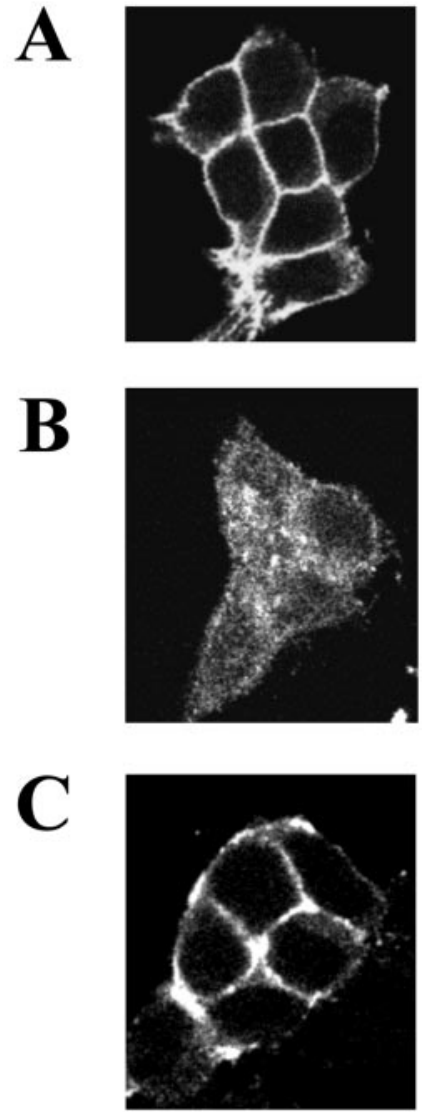

Figure 4. PD98059-induced hDAT cell surface redistribution is an internalization event. $A, B$, Confocal microscopic images of FLAG-hDAT cells incubated in the absence $(A)$ or presence $(B)$ of $50 \mu \mathrm{m}$ PD98059. C, Preincubation of FLAG-hDAT cells with ConA (250 $\mu \mathrm{g} / \mathrm{ml}$ for $20 \mathrm{~min}$ ) reduced the PD98059-induced redistribution of FLAG-hDAT from the plasma membrane to the cystosol. The confocal microscopic images shown are representative of four different experiments (PD98059 vs control) and three experiments (PD98059 vs CoA).

of PD98059-treated cells, indicating that ConA attenuated the loss of cell surface DAT produced by MAPK inhibition. Preincubation with ConA alone (data not shown) did not alter the cell surface distribution of FLAG-hDAT

Consistent with the findings of a decrease in $\left[{ }^{3} \mathrm{H}\right] \mathrm{DA}$ uptake and decreased hDAT cell surface expression, incubation of FLAG-hDAT cells with $50 \mu \mathrm{M}$ PD98059 for 30 min significantly decreased the level of hDAT protein recovered in the biotinylated (cell surface) fractions (Fig. $5 ; 72 \pm 3.0 \%$ of control; $n=4 ; p \leq$ 0.01 , two-tailed $t$ test).

Most plasma membrane proteins are internalized by clathrinmediated endocytosis. The involvement of clathrin-coated pits in mediating the increased cystolic expression evoked by MAPK inhibition was examined by coexpressing the FLAG-hDAT with GFPclathrin. Double-staining experiments were then performed to determine the effect of MAPK inhibition on the localization of FLAGhDAT and GFP-clathrin. Figure 6 shows only puncta of colocalization in untreated cells. After incubation with PD98059 for $30 \mathrm{~min}$, extensive colocalization of GFP-clathrin with FLAG-hDAT is apparent, suggesting that hDAT traffics through the clathrin pathway. Together, these results suggest that the effects of MAPK inhibition result from a clathrin-dependent redistribution of the hDAT. 

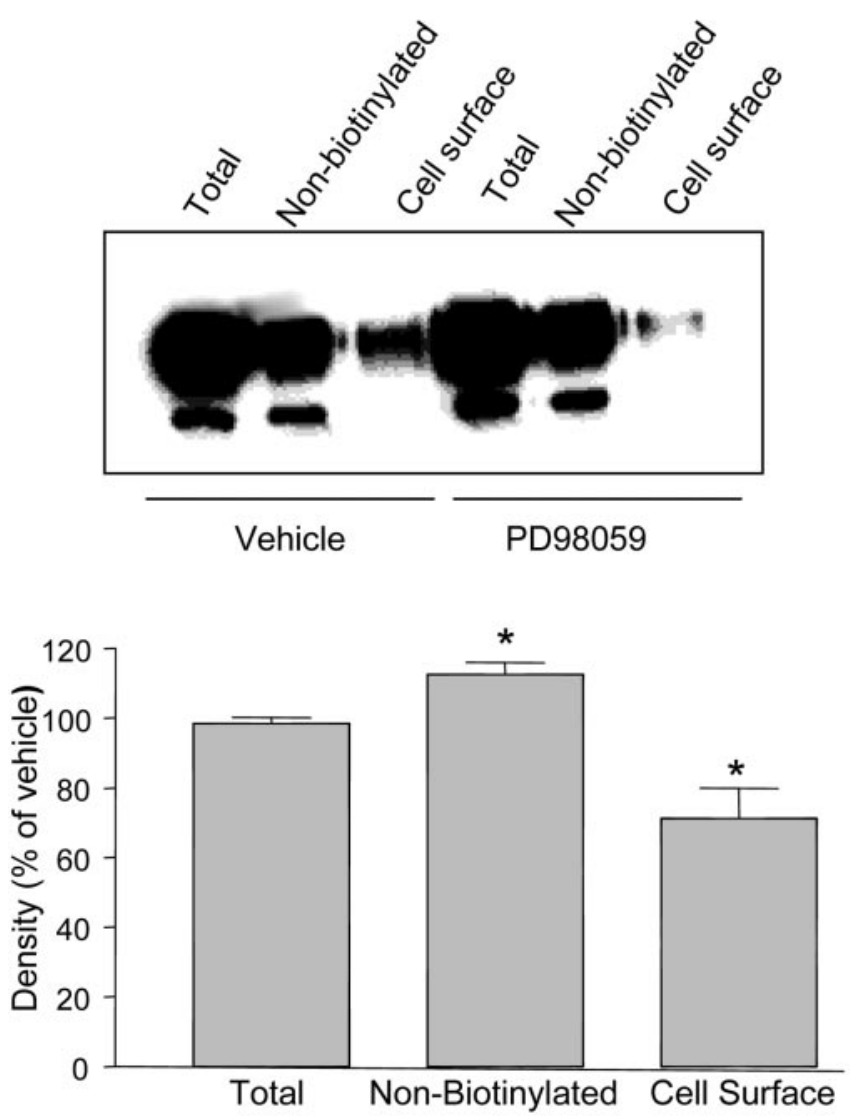

Figure 5. PD98059 induces an hDAT redistribution from the cell surface to an intracellular pool. Cells were treated with $50 \mu \mathrm{m}$ PD98059 or vehicle for 30 min before biotinylation with sulfo-NHS-SS-biotin. Biotinylated (cell surface) and nonbiotinylated (intracellular) proteins were separated with streptavidin beads and analyzed by immunoblot with an hDAT-specific antibody as described in Material and Methods. $A$, Representative immunoblot. $B$, Immunoblots from four separate experiments were scanned densitometrically, and mean values \pm SEM were plotted. Data are expressed as a percentage of vehicle-treated cells. *Significant difference compared with vehicle-treated controls ( $p<0.01$, Student's $t$ test).

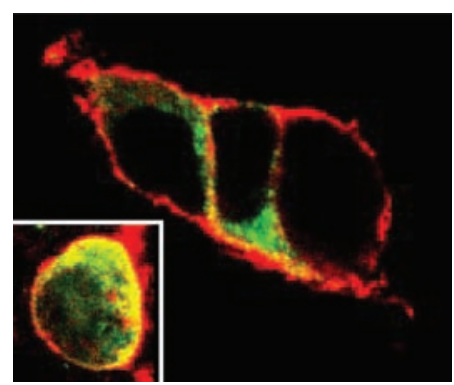

Figure 6. PD98059-induced internalization of FLAG-hDAT is clathrin-mediated. FLAG-hDAT cells were transiently transfected with the neuronal-specific GFP-clathrin light chain. Doublestaining experiments (red fluorescence for the FLAG-hDAT, green fluorescence for clathrin) were performed to determine colocalization of FLAG-hDAT and GFP-clathrin. Main panel, Confocal microscopy revealed little or no puncta of colocalization under control conditions. Inset, In FLAG-hDAT cells exposed for $30 \mathrm{~min}$ to $50 \mu \mathrm{m}$ PD9805, there is extensive colocalization (yellow) between GFP-clathrin and FLAG-hDAT, presumably at the level of endocytotic compartments.

Expression of constitutively active MEK increases $\left[{ }^{3} \mathrm{H}\right] \mathrm{DA}$ uptake in FLAG-hDAT cells

To evaluate whether MAPK stimulation increases the activity of hDAT, EM4 cells were transiently transfected with wild-type MEK or the constitutively active MEK mutant S218E-S222D (Mansour et al., 1994). Consistent with a previous report (Man-
Table 3. $\left[{ }^{3} \mathrm{H}\right] \mathrm{DA}$ uptake in FLAG-hDAT cells transfected with wild-type MEK or the constitutively active MEK mutant

\begin{tabular}{lll}
\hline Type of MEK & $K_{\mathrm{m}}(\mu \mathrm{m})$ & $V_{\max }\left(\mathrm{pmol} \cdot \mathrm{mg} \mathrm{protein}^{-1} \cdot \mathrm{min}^{-1}\right)$ \\
\hline Wild type & $2.47 \pm 0.52$ & $507.0 \pm 19.06$ \\
Active type & $2.47 \pm 0.63$ & $666.2 \pm 32.2^{*}$ \\
\hline
\end{tabular}

Dopamine uptake was done at $25^{\circ} \mathrm{C}$ for $5 \mathrm{~min}$.

${ }^{*} p<0.05$, unpaired $t$ test.

sour et al., 1994), phosphorylated p44 and p42 forms of MAPK were markedly elevated in cells transfected with the S218E-S222D mutant relative to those transfected with the wild-type mutant. Immunoblot analysis of p44 and p42 MAPK revealed an $\sim 20$ fold increase relative to that of wild-type cells ( $p \leq 0.01$, twotailed $t$ test; $n=3$; data not shown). Kinetic analysis of $\left[{ }^{3} \mathrm{H}\right] \mathrm{DA}$ uptake revealed a significant increase ( $p \leq 0.05$, two-tailed $t$ test) in the $V_{\max }$ of DA uptake in FLAG-hDAT cells transfected with constitutively active MEK (Table 3; wild type, $507.0 \pm 19.1$ $\mathrm{pmol} \cdot \mathrm{mg}$ of protein $^{-1} \cdot \mathrm{min}^{-1}$; mutant, $666.2 \pm 32.3$ $\mathrm{pmol} \cdot \mathrm{mg}$ of protein $\left.{ }^{-1} \cdot \min ^{-1} ; n=5\right)$. No change in $K_{\mathrm{m}}$ values was seen (wild type, $2.47 \pm 0.52 \mu \mathrm{M}$; mutant, $2.47 \pm 0.63 \mu \mathrm{M}$ ). Although biotinylation experiments revealed that the increase in DA uptake was associated with an increase in hDAT cell surface expression ( $113 \pm 4 \%$ of wild type; $n=3)$, this effect did not reach statistical significance ( $p=0.06$, two-tailed $t$ test).

\section{Discussion}

These studies demonstrate that the MAPK pathway is constitutively active in striatal synaptosomes and HEK-293 cells expressing an epitope-tagged hDAT. Inhibition of this pathway decreases DA uptake, an effect resulting from a decrease in transport capacity. Using confocal microscopy, we demonstrate that the decreased transport capacity is associated with the clathrin-dependent redistribution of hDAT from the plasma membrane to the cytosol. Furthermore, we show that expression of a constitutively active mutant of MEK kinase in FLAG-hDAT cells increases DA uptake, suggesting a direct correlation between DA uptake and MAPK activity.

DA transport across plasma membranes is a tightly regulated process involving transcriptional and post-transcriptional processes. In the CNS, presynaptic sites of DAT expression are located some distance from sites of gene transcription, limiting the temporal ability of cells to modulate transport capacity and DA uptake from the extracellular space. PKC activation decreases DA transport, whereas inhibitors increase transport (Melikian et al., 1994; Vaughan et al., 1997; Zhu et al., 1997; Pristupa et al., 1998). Evidence that these effects result from alterations in transporter trafficking has been obtained (Pristupa et al., 1998; Daniels and Amara, 1999; Melikian and Buckley, 1999). Although interactions between PKC and MAPKs have been reported (Treisman, 1996), the role of MAPKs in regulating DA uptake and DAT cell surface expression has not been examined. We addressed this issue by using U0126 and PD98059, selective noncompetitive inhibitors of MEK, the dual-specificity kinase that phosphorylates ERK1 and ERK2 (Alessi et al., 1995; Duncia et al., 1998; Favata et al., 1998).

PD98059 and U0126 decreased levels of phosphorylated ERK1 and ERK2 in striatal synaptosomes. These data are consistent with the documented biological activity of these agents and indicate constitutive activation of MAPK in this brain region. Although PI 3-kinase modulates MAPKs in several cell lines, LY294002, a selective PI 3-kinase inhibitor (Vlahos et al., 1994), did not alter ERK1 and ERK2 phosphorylation, suggesting that 
constitutively active PI 3-kinase does not regulate the MAPK cascade in striatum. This finding is of particular interest in view of a recent study showing that PI-3 kinase regulates $\left[{ }^{3} \mathrm{H}\right] \mathrm{DA}$ uptake in striatal synaptosomes (Carvelli et al., 2002) and suggests that the effects of this kinase occur independently of the MAPK pathway.

Incubation of striatal synaptosomes with either U0126 or PD98059 decreased DA uptake. This effect resulted from a reduction in transporter capacity rather than a decrease in affinity. The maximum effect of U0126 was greater than that of PD98059, perhaps because U0126 inhibits both MEK-1 and -2, whereas PD98059 only inhibits MEK-1 (Alessi et al., 1995; Duncia et al., 1998). These data indicate a novel mechanism of DAT regulation by MAPKs and suggest a critical role of the MAPK cascade in regulating presynaptic DA neurotransmission. Furthermore, they suggest that both $\mathrm{p} 44$ and $\mathrm{p} 42$ isoforms of MAPK regulate DA uptake. Whether the decrease in uptake results from the inhibition of MAPK within DA terminals or in other neurons that innervate the striatum remains an unanswered question.

$\mathrm{D}_{2}$ DA receptor antagonists decrease DA uptake in striatum, whereas $\mathrm{D}_{2}$ receptor agonists increase it (Meiergerd et al., 1993; Cass and Gerhardt, 1994). $\kappa$ opioid receptor agonists as well as orphanin FQ also modulate DA uptake (Thompson et al., 2000; Liu et al., 2001). Activation of each of these receptors results in the phosphorylation of p44 and p42 MAPK (Luo et al., 1998; Yan et al., 1999; Jordan et al., 2000). The present findings, therefore, raise the intriguing possibility that GPCR regulation of DAT activity may occur at the level of the MAPK signaling cascade.

Various neurotransmitter transporters undergo internalization, and transporter trafficking may be one mechanism that permits rapid regulation of transporter activity (Bernstein and Quick, 1999; Daniels and Amara, 1999; Duan et al., 1999; Saunders et al., 2000). Activation of PKC by phorbol ester decreases the $V_{\max }$ of DA transport and causes a rapid redistribution of DAT from the plasma membrane to the cytosol (Melikian et al., 1994; Daniels and Amara, 1999). Evidence that PKC regulates the activity and cell surface expression of serotonin transporters has also been obtained (Qian et al., 1997; Ramamoorthy et al., 1998; Bernstein and Quick, 1999). More recent studies have shown that PI 3-kinase regulates the activity and trafficking of both DAT and the norepinephrine transporter (Apparsundaram et al., 2001; Carvelli et al., 2002). Extracellular substrates also influence internalization of transporters, suggesting that trafficking may represent an important mechanism for the regulation of appropriate transport capacity (Qian et al., 1997; Duan et al., 1999; Saunders et al., 2000).

Our studies in HEK 293 cells stably expressing FLAG-hDAT show that MAPK inhibition markedly decreases DA uptake and that this decrease is associated with a redistribution of immunofluorescence from the plasma membrane to the cytosol. A reduction in the $V_{\max }$ of [ $\left.{ }^{3} \mathrm{H}\right] \mathrm{DA}$ uptake and increased cytosolic localization of FLAG-hDAT were observed after either U0126 or PD98059 treatment. Biotinylation studies confirmed that PD98059 reduces cell surface hDAT expression and that the magnitude of this effect is comparable with the decrease in $V_{\max }$ produced by this agent. Our results extend those of a recent report (Rothman et al., 2002), which showed that treatment with $10 \mu \mathrm{M}$ PD98059 decreased the $B_{\max }$ for $\left[{ }^{125} \mathrm{I}\right] 3$-(4-iodophenyl)-8methyl-8-aza-bicyclo[3,2,1] octane-2-carboxylic acid methyl ester binding and indicate that this decrease may be mediated, in part, by the redistribution of DAT from the membrane to the cytosolic compartment. Additional studies, however, in striatal slices or in vivo are needed to test this hypothesis.
ConA binds to terminal mannose residues on cell surface glycoproteins and, by stabilizing their lateral mobility, prevents internalization (Lis and Sharon, 1986). Preincubation of cells with ConA reduced the increase in cytosolic distribution of FLAGhDAT produced by both U0126 and PD98059, suggesting that hDAT redistribution reflects an internalization event. Internalization of many membrane proteins is mediated by formation of clathrin-coated pits. We found that colocalization of FLAGhDAT and clathrin is restricted to discrete puncta in the absence of MAPK inhibition. However, after treatment of cells with PD98059, extensive cytosolic colocalization of FLAG-hDAT and GFP-clathrin is seen.

PKC activation increases internalization of the hDAT by a clathrin-mediated process (Daniels and Amara, 1999). A similar effect is observed in response to PI 3-kinase inhibition (Carvelli et al., 2002). The finding that MAPK inhibition also induces the clathrin-dependent redistribution of hDAT suggests a more global role of kinase cascades in regulating DAT trafficking and DA neuronal homeostasis. Furthermore, it suggests that in contrast to PKC activation, which decreases DAT uptake and cell surface expression, constitutive MAPK activation, like that of PI 3-kinase, serves to inhibit translocation of DAT from the plasma membrane, to speed the return of internalized DAT to the membrane, or both.

In the absence of MAPK inhibitors, incubation of cells with ConA did not modify hDAT cell surface expression, suggesting that the fraction of recycling transporters in HEK 293 cells, in contrast to that in PC12 cells (Melikian and Buckley, 1999; Loder and Melikian, 2003), is modest. Consistent with this hypothesis, confocal microscopy revealed only puncta of colocalized DAT and clathrin in untreated cells. Alternatively, ConA may decrease the translocation rate of DAT both to and from the plasma membrane, resulting in no net change in hDAT cell surface expression. The finding, however, that MAPK inhibition increases intracellular DAT levels strongly suggests that phosphorylated ERK1 and ERK2 regulate the amount of DAT expressed on the plasma membrane and that MAPK activation may be one mechanism that limits rapid and extensive hDAT recycling in HEK 293 cells. In this regard, it should be noted that levels of phosphorylated MAPK as well as the $V_{\max }$ of DA uptake were significantly increased in cells transfected with a constitutively active MEK mutant. However, only a modest increase in hDAT cell surface expression was seen. This latter finding is not unexpected in view of the high level of hDAT cell surface expression apparent in wildtype cells $(\sim 75 \%$;). Nonetheless, the greater increase in transport than cell surface expression suggests that overexpression of phosphorylated MAPK increases DA uptake by affecting both transporter turnover and trafficking.

The mechanism by which MAPKs regulate DAT trafficking is unknown. The presence of consensus sites for PKC and other kinases on DAT suggests that alterations in the phosphorylation state of the transporter may occur in parallel with or lead to transporter redistribution. PKC phosphorylates DAT and other monoamine transporters (Qian et al., 1997; Vaughan et al., 1997). The demonstration that an N-terminally truncated DAT is not phosphorylated but is, however, internalized after PKC activation suggests that although direct DAT phosphorylation may modulate trafficking, phosphorylation of other proteins (e.g., kinases and phosphatases) may be essential for DAT internalization (Granas et al., 2003). Because PKC activation increases DAT internalization, as does inhibition of either MAPK or PI 3-kinase, if direct DAT phosphorylation is involved in both processes, then these latter kinases must act on different phosphorylation sites on 
DAT. Alternatively, if direct transporter phosphorylation modulates DAT activity, trafficking, or both, it may occur via kinases that are downstream of, or differentially regulated by, PKC compared with MAPK and PI 3-kinase. Regardless of the mechanism, the present findings suggest that MAPK activation may be an important mechanism that opposes PKC-mediated decreases in DA uptake and hDAT cell surface expression

Redistribution of membrane proteins has been implicated in synaptic plasticity and neurotransmitter homeostasis (Man et al., 2000). MAPKs have been implicated in the regulation of gene transcription, cell growth, and differentiation (Drewes et al., 1992; Blenis, 1993; Treisman, 1996). The demonstration that MAPKs regulate DA uptake and DAT trafficking suggests that the MAPK cascade may contribute to the regulation of DA signaling and synaptic strength. Indeed, a recent study (Valjent et al., 2000) has shown that the DA uptake inhibitor cocaine stimulates MAPK. Moreover, cocaine increases DA uptake by promoting increased DAT cell surface expression (Daws et al., 2002). The present data, therefore, suggest that cocaine stimulation of MAPK may be one mechanism by which cocaine increases DAT activity, thereby opposing the increase in extracellular DA produced by its direct blockade of transport.

\section{References}

Alessi DR, Cuenda A, Cohen P, Dudley DT, Saltiel AR (1995) PD 098059 is a specific inhibitor of the activation of mitogen-activated protein kinase kinase in vitro and in vivo. J Biol Chem 270:27489-27494.

Amara SG, Kuhar MJ (1993) Neurotransmitter transporters: recent progress. Annu Rev Neurosci 16:73-93.

Apparsundaram S, Schroeter S, Giovanetti E, Blakely RD (1998) Acute regulation of norepinephrine transport: II. PKC-modulated surface expression of human norepinephrine transporter proteins. J Pharmacol Exp Ther 287:744-751.

Apparsundaram S, Sung U, Price RD, Blakely RD (2001) Traffickingdependent and -independent pathways of neurotransmitter transporter regulation differentially involving p38 mitogen-activated protein kinase revealed in studies of insulin modulation of norepinephrine transport in SK-N-SH cells. J Pharmacol Exp Ther 299:666-677.

Batchelor M, Schenk JO (1998) Protein kinase A activity may kinetically upregulate the striatal transporter for dopamine. J Neurosci 18:10304-10309.

Bernstein EM, Quick MW (1999) Regulation of $\gamma$-aminobutyric acid (GABA) transporters by extracellular GABA. J Biol Chem 274:889-895.

Blenis J (1993) Signal transduction via the MAP kinases: proceed at your own RSK. Proc Natl Acad Sci USA 90:5889-5892.

Carvelli L, Morón JA, Kahlig KM, Ferrer JV, Sen N, Lechleiter JD, LeebLundberg LM, Merrill G, Lafer EM, Ballou LM, Shippenberg TS, Javitch JA, Lin RZ, Galli A (2002) PI 3-kinase regulation of dopamine uptake. J Neurochem 81:859-869.

Cass WA, Gerhardt GA (1994) Direct in vivo evidence that D2 dopamine receptors can modulate dopamine uptake. Neurosci Lett 176:259-263.

Cass WA, Larson G, Fitzpatrick FA, Zahniser NR (1991) Inhibitors of arachidonic acid metabolism: effects on rat striatal dopamine release and uptake. J Pharmacol Exp Ther 257:990-996.

Copeland BJ, Vogelsberg V, Neff NH, Hadjiconstantinou M (1996) Protein kinase $\mathrm{C}$ activators decrease dopamine uptake into striatal synaptosomes. J Pharmacol Exp Ther 277:1527-1532.

Cussac D, Newman-Tancredi A, Pasteau V, Millan MJ (1999) Human dopamine $\mathrm{D}(3)$ receptors mediate mitogen-activated protein kinase activation via a phosphatidylinositol 3-kinase and an atypical protein kinase C-dependent mechanism. Mol Pharmacol 56:1025-1030.

Daniels GM, Amara SG (1999) Regulated trafficking of the human dopamine transporter: clathrin-mediated internalization and lysosomal degradation in response to phorbol esters. J Biol Chem 274:35794-35801.

Daws LC, Callaghan PD, Moron JA, Kahlig KM, Shippenberg TS, Javitch JA, Galli A (2002) Cocaine increases dopamine uptake and cell surface expression of dopamine transporters. Biochem Biophys Res Commun 290:1545-1550.

Drewes G, Lichtenberg-Kraag B, Doring F, Mandelkow EM, Biernat J, Goris J,
Doree M, Mandelkow E (1992) Mitogen activated protein (MAP) kinase transforms tau protein into an Alzheimer-like state. EMBO J 11:2131-2138.

Duan S, Anderson CM, Stein BA, Swanson RA (1999) Glutamate induces rapid upregulation of astrocyte glutamate transport and cell-surface expression of GLAST. J Neurosci 19:10193-10200.

Duncia JV, Santella JB, Higley CA, Pitts WJ, Wityak J, Frietze WE, Rankin FW, Sun JH, Earl RA, Tabaka AC, Teleha CA, Blom KF, Favata MF, Manos EJ, Daulerio AJ, Stradley DA, Horiuchi K, Copeland RA, Scherle PA, Trzaskos JM, et al. (1998) MEK inhibitors: the chemistry and biological activity of U0126, its analogs, and cyclization products. Bioorg Med Chem Lett 8:2839-2844.

Favata MF, Horiuchi KY, Manos EJ, Daulerio AJ, Stradley DA, Feeser WS, Van Dyk DE, Pitts WJ, Earl RA, Hobbs F, Copeland RA, Magolda RL, Scherle PA, Trzaskos JM (1998) Identification of a novel inhibitor of mitogen-activated protein kinase kinase. J Biol Chem 273:18623-18632.

Ferrer JV, Javitch JA (1998) Cocaine alters the accessibility of endogenous cysteines in putative extracellular and intracellular loops of the human dopamine transporter. Proc Natl Acad Sci USA 95:9238-9243.

Fleckenstein AE, Pogun S, Carroll FI, Kuhar MJ (1996) Recovery of dopamine transporter binding and function after intrastriatal administration of the irreversible inhibitor RTI-76 [ 3 beta-(3p-chlorophenyl) tropan-2 beta-carboxylic acid $p$ - isothiocyanatophenylethyl ester hydrochloride]. J Pharmacol Exp Ther 279:200-206.

Flood DG, Finn JP, Walton KM, Dionne CA, Contreras PC, Miller MS, Bhat RV (1998) Immunolocalization of the mitogen-activated protein kinases p42MAPK and JNK1, and their regulatory kinases MEK1 and MEK4, in adult rat central nervous system. J Comp Neurol 398:373-392.

Gerfen CR, Miyachi S, Paletzki R, Brown P (2002) D1 dopamine receptor supersensitivity in the dopamine-depleted striatum results from a switch in the regulation of ERK1/2/MAP kinase. J Neurosci 22:5042-5054.

Giros B, Caron MG (1993) Molecular characterization of the dopamine transporter. Trends Pharmacol Sci 14:43-49.

Grace AA (1995) The tonic/phasic model of dopamine system regulation: its relevance for understanding how stimulant abuse can alter basal ganglia function. Drug Alcohol Depend 37:111-129.

Granas C, Ferrer J, Loland CJ, Javitch JA, Gether U (2003) N-terminal truncation of the dopamine transporter abolishes phorbol ester and substance $P$ receptor stimulated phosphorylation without impairing transporter internalization. J Biol Chem 278:4990-5000.

Hawes BE, van Biesen T, Koch WJ, Luttrell LM, Lefkowitz RJ (1995) Distinct pathways of Gi- and Gq-mediated mitogen-activated protein kinase activation. J Biol Chem 270:17148-17153.

Horn AS (1990) Dopamine uptake: a review of progress in the last decade. Prog Neurobiol 34:387-400.

Huff RA, Vaughan RA, Kuhar MJ, Uhl GR (1997) Phorbol esters increase dopamine transporter phosphorylation and decrease transport Vmax. J Neurochem 68:225-232.

Hyman SE (1996) Addiction to cocaine and amphetamine. Neuron 16:901-904.

Igishi T, Gutkind JS (1998) Tyrosine kinases of the Src family participate in signaling to MAP kinase from both Gq- and Gi-coupled receptors. Biochem Biophys Res Commun 244:5-10.

Jones SR, Gainetdinov RR, Jaber M, Giros B, Wightman RM, Caron MG (1998) Profound neuronal plasticity in response to inactivation of the dopamine transporter. Proc Natl Acad Sci USA 95:4029-4034.

Jordan BA, Cvejic S, Devi LA (2000) Kappa opioid receptor endocytosis by dynorphin peptides. DNA Cell Biol 19:19-27.

Loder MK, Melikian HE (2003) The dopamine transporter constitutively internalizes and recycles in a protein kinase C-regulated manner in stably transfected PC12 cell line. J Biol Chem 278:22168-22174.

Lee JC, Kassis S, Kumar S, Badger A, Adams JL (1999) p38 mitogenactivated protein kinase inhibitors: mechanisms and therapeutic potentials. Pharmacol Ther 82:389-397.

Lis H, Sharon N (1986) Lectins as molecules and as tools. Annu Rev Biochem 55:35-67.

Liu Z, Wang Y, Zhang J, Ding J, Guo L, Cui D, Fei J (2001) Orphanin FQ: an endogenous antagonist of rat brain dopamine transporter. NeuroReport 12:699-702.

Luo Y, Kokkonen GC, Wang X, Neve KA, Roth GS (1998) D2 dopamine receptors stimulate mitogenesis through pertussis toxin-sensitive $\mathrm{G}$ pro- 
teins and Ras-involved ERK and SAP/JNK pathways in rat C6-D2L glioma cells. J Neurochem 71:980-990.

Man YH, Lin JW, Ju WH, Ahmadian G, Liu L, Becker LE, Sheng M, Wang YT (2000) Regulation of AMPA receptor-mediated synaptic transmission by clathrin-dependent receptor internalization. Neuron 25:649-662.

Mansour SJ, Matten WT, Hermann AS, Candia JM, Rong S, Fukasawa K, Vande Woude GF, Ahn NG (1994) Transformation of mammalian cells by constitutively active MAP kinase kinase. Science 265:966-970.

Mayfield RD, Zahniser NR (2001) Dopamine D(2) receptor regulation of the dopamine transporter expressed in Xenopus laevis oocytes is voltageindependent. Mol Pharmacol 59:113-121.

Meiergerd SM, Patterson TA, Schenk JO (1993) D2 receptors may modulate the function of the striatal transporter for dopamine: kinetic evidence from studies in vitro and in vivo. J Neurochem 61:764-767.

Melikian HE, Buckley KM (1999) Membrane trafficking regulates the activity of the human dopamine transporter. J Neurosci 19:7699-7710.

Melikian HE, McDonald JK, Gu H, Rudnick G, Moore KR, Blakely RD (1994) Human norepinephrine transporter: biosynthetic studies using a site-directed polyclonal antibody. J Biol Chem 269:12290-12297.

Ortiz J, Harris HW, Guitart X, Terwilliger RZ, Haycock JW, Nestler EJ (1995) Extracellular signal-regulated protein kinases (ERKs) and ERK kinase (MEK) in brain: regional distribution and regulation by chronic morphine. J Neurosci 15:1285-1297.

Pristupa ZB, McConkey F, Liu F, Man HY, Lee FJ, Wang YT, Niznik HB (1998) Protein kinase-mediated bidirectional trafficking and functional regulation of the human dopamine transporter. Synapse 30:79-87.

Qian Y, Galli A, Ramamoorthy S, Risso S, DeFelice LJ, Blakely RD (1997) Protein kinase $\mathrm{C}$ activation regulates human serotonin transporters in HEK-293 cells via altered cell surface expression. J Neurosci 17:45-57.

Ramamoorthy S, Blakely RD (1999) Phosphorylation and sequestration of serotonin transporters differentially modulated by psychostimulants. Science 285:763-766.

Ramamoorthy S, Giovanetti E, Qian Y, Blakely RD (1998) Phosphorylation and regulation of antidepressant-sensitive serotonin transporters. J Biol Chem 273:2458-2466.

Rees S, Coote J, Stables J, Goodson S, Harris S, Lee MG (1996) Bicistronic vector for the creation of stable mammalian cell lines that predisposes all antibiotic-resistant cells to express recombinant protein. Biotechniques 20:102-104.

Robbins AK, Horlick RA (1998) Macrophage scavenger receptor confers an adherent phenotype to cells in culture. Biotechniques 25:240-244.

Rosen LB, Ginty DD, Weber MJ, Greenberg ME (1994) Membrane depolarization and calcium influx stimulate MEK and MAP kinase via activation of Ras. Neuron 12:1207-1221.

Rothman RB, Dersch CM, Carroll FI, Ananthan S (2002) Studies of the biogenic amine transporters. VIII: identification of a novel partial inhib- itor of dopamine uptake and dopamine transporter binding. Synapse 43:268-274.

Saunders C, Ferrer JV, Shi L, Chen J, Merrill G, Lamb ME, Leeb-Lundberg LM, Carvelli L, Javitch JA, Galli A (2000) Amphetamine-induced loss of human dopamine transporter activity: an internalization-dependent and cocaine-sensitive mechanism. Proc Natl Acad Sci USA 97:6850-6855.

Schlessinger J, Ullrich A (1992) Growth factor signaling by receptor tyrosine kinases. Neuron 9:383-391.

Self DW, Nestler EJ (1995) Molecular mechanisms of drug reinforcement and addiction. Annu Rev Neurosci 18:463-495.

Thompson AC, Zapata A, Justice Jr JB, Vaughan RA, Sharpe LG, Shippenberg TS (2000) Kappa-opioid receptor activation modifies dopamine uptake in the nucleus accumbens and opposes the effects of cocaine. J Neurosci 20:9333-9340.

Treisman R (1996) Regulation of transcription by MAP kinase cascades. Curr Opin Cell Biol 8:205-215.

Uchikawa T, Kiuchi Y, Yura A, Nakachi N, Yamazaki Y, Yokomizo C, Oguchi $\mathrm{K}$ (1995) $\mathrm{Ca}(2+)$-dependent enhancement of $[3 \mathrm{H}]$ dopamine uptake in rat striatum: possible involvement of calmodulin-dependent kinases. J Neurochem 65:2065-2071.

Valjent E, Corvol JC, Pages C, Besson MJ, Maldonado R, Caboche J (2000) Involvement of the extracellular signal-regulated kinase cascade for cocaine-rewarding properties. J Neurosci 20:8701-8709.

Vanhoutte P, Barnier JV, Guibert B, Pages C, Besson MJ, Hipskind RA, Caboche J (1999) Glutamate induces phosphorylation of Elk-1 and CREB, along with c-fos activation, via an extracellular signal-regulated kinase-dependent pathway in brain slices. Mol Cell Biol 19:136-146.

Vaughan RA, Huff RA, Uhl GR, Kuhar MJ (1997) Protein kinase C-mediated phosphorylation and functional regulation of dopamine transporters in striatal synaptosomes. J Biol Chem 272:15541-15546.

Vlahos CJ, Matter WF, Hui KY, Brown RF (1994) A specific inhibitor of phosphatidylinositol 3-kinase 2-(4-morpholinyl)-8-phenyl-4H-1benzopyran-4-one (LY294002). J Biol Chem 269:5241-5248.

Welch SM, Justice JB (1996) Regulation of dopamine uptake in rat striatal tissue by NMDA receptors as measured using rotating disk electrode voltammetry. Neurosci Lett 217:184-188.

Yan Z, Feng J, Fienberg AA, Greengard P (1999) D(2) dopamine receptors induce mitogen-activated protein kinase and cAMP response elementbinding protein phosphorylation in neurons. Proc Natl Acad Sci USA 96:11607-11612.

Zhang L, Coffey LL, Reith ME (1997) Regulation of the functional activity of the human dopamine transporter by protein kinase C. Biochem Pharmacol 53:677-688.

Zhu SJ, Kavanaugh MP, Sonders MS, Amara SG, Zahniser NR (1997) Activation of protein kinase $C$ inhibits uptake, currents and binding associated with the human dopamine transporter expressed in Xenopus oocytes. J Pharmacol Exp Ther 282:1358-1365. 